\title{
Assim na terra como no céu
}

\author{
Maria Filomena Pinto da Costa Coelho*
}

Bastos, Mário Jorge da Motta. Assim na terra como no céu... Paganismo, cristianismo, senhores e camponeses na Alta Idade Média ibérica (séculos IV-VIII). São Paulo: EdUSP, 2013. 264 p.

Eis um livro que tem uma grande contribuição a dar: é um belo exercício de história. Seu autor, Mário Jorge da Motta Bastos, é professor de História Medieval na Universidade Federal Fluminense e desenvolveu sua trajetória como pesquisador sobre a Idade Média ibérica. Mas, para este historiador, mais importante do que o tempo e o espaço sobre os quais se debruça é a perspectiva da qual se parte. Neste sentido, ele deixa as coisas claras desde o início: a história só é possível a partir do presente, como um problema que se coloca ao passado, no intuito de dar sentido à vida dos homens e mulheres em sociedade. Mário Jorge Bastos aparece em cada palavra que escreve - náo apenas nas entrelinhas - , assumindo o protagonismo do texto, e fazendo jus à tradiçáo marxista, com a qual se alinha. Portanto, trata-se de um livro de história que expressa com muita clareza de onde se parte, os caminhos que se pretende percorrer e de que forma se fará esse percurso.

Nos tempos que correm, em que nos vamos acostumando com o "mais ou menos", não deve passar despercebido o trabalho acadêmico realizado com seriedade e competência e, no que tange à disciplina da História, dentro de parâmetros que permitem acompanhar a construçáo do objeto de estudo, as interpretaçóes que se tecem sobre o passado e, finalmente, as conclusóes a que se chega. Creio que é somente sobre essa base que o trabalho do historiador pode, ou não, ser considerado (julgado?) legítimo. Assim, o livro é um exercício de história, cuja extrema transparência permite ao leitor acessar de forma segura os fundamentos teóricos e os problemas que se entrelaçam no texto e que conduziram o autor em sua leitura dos documentos.

No intuito de prestar tributo à franqueza acadêmica que Mário Jorge Bastos derrama em sua obra, devo dizer que não sou marxista. Entretanto, li Assim na terra como no céu... com o prazer do historiador que encontra um bom livro de história. $\mathrm{Na}$ forma como o texto é redigido, todos os aspectos são importantes: desde os desafios de ser marxista no mundo de hoje - com todas as idiossincrasias que a palavra encerra - 
passando pelas dificuldades que o historiador enfrenta ao sistematizar de forma compreensível aquilo que desejaria que fosse apreendido por um só golpe de vista, até o hermetismo de algumas fontes primárias. $\mathrm{O}$ autor póe tudo a descoberto.

Assim na terra como no céu... parte de um problema que a historiografia dedicada à alta Idade Média do Ocidente entende como fundamental: a conversão ao cristianismo. Portanto, trata-se de um tema que já foi esmiuçado por muitos autores, apoiado por um leque de explicaçóes e de abordagens igualmente vasto. A proposta de Mário Jorge Bastos desenvolve-se em seis capítulos: 1) O processo de senhorializaçáo da sociedade ibérica; 2) A Igreja no quadro da sociedade senhorial; 3) A revelaçáo divina; 4) Continuidade ou transformaçáa?; 5) Caráter, relações e campos de intervenção do poder divino; 6) Os santos e a liturgia. É por meio deste plano que o autor pretende explicar de que maneira se entrelaçam paganismo, cristianismo, senhores e camponeses na Península Ibérica, entre os séculos IV e VIII.

Diferentemente de muitas das interpretaçôes já clássicas da historiografia que versam sobre a temática, o livro apoia-se numa premissa basilar: o estudo do passado só faz sentido se ancorado na vida em sociedade. Portanto, para que a "conversão ao cristianismo" alcance o patamar de um problema de história, na sua totalidade, precisa ser entendido em sociedade, revelando, de uma só vez, suas implicaçôes culturais, políticas e econômicas. São as transformaçôes ocorridas nas relaçôes sociais que explicam a conversão e as características de que ela se reveste. De forma mais ampla,

Qualquer tentativa de enfrentamento, prático e/ou teórico, do "núcleo duro" das abstraçóes religiosas deve orientar-se pela apreensão da lógica social em meio à qual essas se inscrevem, considerandose a articulação das abstrações com as relações sociais e os modos de produção historicamente específicos. (p. 19)

Fazer história é desvendar a essência da articulação das globalidades sociais historicamente dadas, nível fundamental de seu conhecimento porque capaz de explicar, num mesmo movimento, o funcionamento real da sociedade e a aparência que a mesma assume para seus integrantes (...), porque permite inscrever a religiáo nos fluxos históricos globais nos quais a mesma se insere, e não como um elemento secundário, reflexivo ou "epifenomênico" em relação aos processos mais essenciais, porque "mais materiais", mas como um elemento primário essencial à articulação das sociedades, em especial daquelas historicamente anteriores ao advento do capitalismo. (p. 20)

De um só golpe, Mário Jorge Bastos critica "gregos e troianos". A religião não pode ser entendida pelos historiadores numa dimensão mágica, capaz de por si mudar a sociedade, nem tampouco como uma manifestação de somenos importância, mais adequada aos estudos sobre a cultura. Ambas as posiçóes, táo comuns na historiografia, e que travaram ruidosas batalhas acadêmicas, fazem exatamente a mesma coisa: retiram a religiấo da história. 
O desafio de trazer a religiáo para dentro da história é complexo, uma vez que, para além de exigir o estudo e interpretação da própria sociedade em análise, supóe ainda o diálogo crítico com os grandes temas da síntese historiográfica, como é o caso da transição/passagem da Antiguidade à Idade Média, na qual os historiadores entendem que a conversão ao cristianismo teve um papel fundamental. Neste caso, o livro apresenta já na introdução a maneira como se pretende enfrentar o problema, além de resumir brevemente as principais correntes e suas implicaçôes. A velha dicotomia "cristianismo $\times$ paganismo" ainda é considerada pelo autor como um aspecto importante a ser discutido, uma vez que as soluçóes propostas nos últimos tempos pelos historiadores não ajudam a explicar a religiâo em sociedade ("no âmago das relaçôes sociais"). Ora se afirma a vitória do cristianismo, ora a resistência do paganismo, numa lógica de forças monolíticas que se enfrentam, e cujos resultados são interpretados às vezes como virtude, às vezes como desvio. Mensuram-se, até mesmo, os níveis de paganismo e de cristianismo!

A saída, para o autor, encontra-se na possibilidade de atribuir à cultura a dimensão de amálgama, como resultado do sentido que a sociedade constrói sobre suas mudanças na história. Assim, reconhece-se uma aproximação às propostas do historiador inglês marxista Edward P. Thompson, para quem a cultura representava um nível de análise fundamental. Daí deriva também a defesa da utilização do conceito de classe para se estudar a sociedade ibérica, uma vez que não se trataria de "uma categoria estática, o que supôe uma derivação mecânica de classes que surgiriam, imediatamente, das próprias relaçôes de produção, desconsiderando-se as relaçóes sociais de mais amplo teor nas quais estas se inserem" (p. 46). Seguindo a Thompson, consistiria em compreender que "as classes 'acontecem' ao viverem, os homens e as mulheres, suas relaçôes de produção, e ao experimentarem suas situaçóes determinantes, dentro de um conjunto de relaçôes sociais com uma cultura e expectativas herdadas, e ao modelarem estas experiências em formas culturais" (p. 46).

Para atingir o objetivo proposto, Mário Jorge Bastos parte, então, da sociedade ibérica. Em seus primórdios, identifica as transformaçôes cruciais que explicam o sentido que o cristianismo alcançou, encontrando-as na constituição da família. Com base num corpus documental rico e variado, e já muito trilhado pelos historiadores, o autor desvela as mudanças que se operaram no seio das famílias senhoriais e camponesas, cujo resultado mais evidente foi a nucleação, em detrimento do modelo da família extensa, acompanhada de um sistema de inter-relaçóes sociais verticais do parentesco, que coloca a aristocracia no vértice dessa relação.

A Igreja, como instituição basilar do período, somente poderá ser compreendida a partir do papel que aquela aristocracia assume, sobretudo ao nível local, na reelaboração social dessas estruturas de parentesco. Portanto, a Igreja, com seu inegável crescimento, é fruto dessa aristocracia e do campesinato, e não uma espécie de guardiã da virtude institucional, que a duras penas sobrevive à ignorância da sociedade e das 
superstiçôes pagãs. $O$ título do segundo capítulo, "A igreja no quadro da sociedade senhorial", não deixa dúvidas quanto à posição do autor com relação ao imponente legado jurídico que essa instituição nos deixou para o período visigodo, e que costuma influenciar os historiadores:

É totalmente outra a perspectiva que assumo, tendo em vista que o objeto deste estudo não é a doutrina jurídica da igreja, mas são as práticas e relaçôes sociais efetivas que estruturaram a instituição e a sociedade global na qual a mesma estava inserida. Nesse sentido, a recorrência da afirmação, o ajuste e a ampliação daquele conjunto de normas expressam as tensões e os conflitos característicos do funcionamento contraditório da realidade social ibérica do período, o que explica a incapacidade dos legisladores de promover a sua plena resolução. (p. 104-105)

No que se refere aos níveis inferiores da sociedade, a Igreja faz-se representar nos párocos, cujas condiçôes jurídicas não diferem muito daquelas que atam os camponeses aos senhores. São, portanto, clérigos dependentes no âmbito do senhorio. Neste sentido, a conclusão do autor aponta para o papel primordial que a Igreja alcançou na qualidade de fruto mais visível da sociedade senhorial.

Como dito, as fontes documentais que embasam o livro são aquelas já conhecidas pela historiografia. No quarto capítulo, Mário Jorge Bastos apoia-se num desses famosos documentos, De corretione rusticorum, de Martinho de Braga, no intuito de desve- lar os eixos centrais da argumentação cristã, sem deixar de destacar as formas como a historiografia costuma interpretar esse tipo de discurso. Com relação ao primeiro aspecto, é importante compreender que a ortodoxia era atravessada por uma infinidade de interpretaçóes e de disputas eclesiásticas em torno da verdade. Os concílios são reveladores desse ambiente de multiplicidades teológicas, que devem ser explicados também na perspectiva da luta pelo reconhecimento de uma única autoridade que exercesse o poder, e que preservasse a Igreja da total entropia que os particularismos supunham. Assim, é imprescindível que o historiador não perca de vista a fragilidade da fronteira entre heresia e ortodoxia, que se estabelecia ao sabor dessas disputas. $\mathrm{O}$ autor sugere que é justamente sobre essa elasticidade que se vai construindo a unidade da Igreja, muito embora se deva afastar completamente aquela surrada ideia de que a instituição virtuosa cede, de forma inteligente e calculada, frente à ignorância e ao paganismo para não perder demasiado terreno, ou, então, aquela outra interpretação de que a Igreja se desvirtua, devido à "paganizaçáo" de seus membros. A mensagem mais importante de Martinho de Braga, em seu sermão, incide sobre a forma (súmula) como "vincula os crentes ao projeto global de ordenação social deliberado pelas elites clericais" (p. 123), revelada pela divindade. Ignorar a vontade de Deus é o caminho para a perdição, que só pode ser evitado por meio da submissáo àqueles que poderão conduzir à verdade: o clero ortodoxo. Somente este pode identificar o que é sagrado, bem como as práticas corretas de 
devoção, as quais necessariamente devem ter a sua intermediação. Caso contrário, trata-se de manifestaçôes demoníacas e pagãs que devem ser suprimidas, sob a pena de condenação eterna. A estratégia do discurso de Martinho, para impossibilitar que essas manifestaçôes possam ser vistas como parte de um "sistema religioso concorrente", é retirar-lhes qualquer conteúdo sagrado, e apresentá-las como práticas laicas e históricas. Trata-se, portanto, de uma proposta religiosa que quer abarcar a realidade total e colocar a Igreja como a única capaz de realizar plenamente a história humana, de acordo com os desígnios de Deus, e a elite clerical como a autoridade cognitiva cristá que interpreta corretamente o mundo.

Do que se disse até aqui, depreende-se um projeto político de hegemonia. Este conceito será apresentado pelo autor de maneira a ressaltar a necessidade de entendê-lo numa perspectiva dinâmica, de constantes transformaçôes, coisa que de resto fez a elite cristã ibérica. Se para os historiadores parece importante decidir se a época era mais de continuidades ou de rupturas, para esses medievais era na tradição que se ancorava o movimento da história. As mudanças que eles propunham eram "uma versão do passado que deve ligar-se ao presente e ratificá-lo, inclusive pelas transformaçôes que se impóem à sua plena adequação" (p. 138). A hegemonia assenta-se no passado, na tradição, e mesmo que o historiador decida tratar-se de 'reminiscência/sobrevivência', ela é vivida com o significado que o presente lhe atribui. Ao mesmo tempo, é preciso não esquecer que a hegemonia eficaz precisa con- tar com o 'consentimento dos dominados' — conceito de Maurice Godelier -, o qual se obtém graças à constante reafirmaçáo dos sentidos do poder, que se assenta na "partilha das representaçôes do mundo" (p. 152). Ao desenvolver os argumentos, Mário Jorge Bastos deixa bastante clara a inutilidade das mediçóes sobre o que há de continuidade ou de ruptura; o importante é que o historiador náo deixe de explicar de que forma esses aspectos se amalgamam no cotidiano da sociedade. A chave reside em ampliar os horizontes do que se entende por economia na Idade Média, o que permitirá concluir que "toda naturalização das relaçóes sociais de produção desemboca, necessariamente, em sua sobrenaturalizaçáo" (p. 158). Portanto, o fenômeno alcança senhores e camponeses que elaboram e dáo sentido às relaçôes que estabelecem entre si e com a natureza, por meio da religiáo. Tal proposta afasta-se daquelas que reduzem a religiáo ao nível das ideias, como se fosse possível partir unicamente do pensamento para desvendar seu significado. Apoiado em Marx, o autor sublinha que "a religiâo remete ao quadro geral da estrutura social e a processos sociais concretos (...) isto é, a uma apreensáo global da sociedade, uma vez que constitui e expressa suas hierarquias e desigualdades, imiscuindo-se aos processos de dominação e resistência" (p. 164).

A proposta que o cristianismo oferece à sociedade nos primeiros séculos da Idade Média é englobante, de acordo com a máxima de que o poder divino tudo abarca. Tal capacidade de intervençáo de Deus na vida dos homens é visível nos escritos de Ambrósio, Agostinho, Isidoro de Sevilha, 
Aurélio Prudêncio, Ildefonso de Toledo e outros autores a quem recorre Mário Jorge Bastos para fundamentar sua reflexão. Assim, as relaçôes sociais são também uma preocupação da divindade, que se manifesta por meio da sacralização dos laços de dependência, da fidelidade e dos vínculos pessoais. A retórica do cristianismo revela uma profunda interligaçáo entre o plano terrestre e o celestial, não como simples estratégia de legitimação da ordem social, mas como resultado da profunda imbricação entre as relaçôes sociais de produção e o plano religioso. A própria monarquia visigoda constrói-se, como prática e discurso, sobre a concepção do ungido de Deus, senhor de terras e de homens, coisa que náo o diferenciava qualitativamente do tipo de poder que era exercido pela aristocracia.

A difusão dos valores sociais da aristocracia cristã assume especial visibilidade com o culto aos santos e às suas relíquias. Criam-se ambientes onde se materializa o modelo e difundem-se narrativas. Por um lado, os lugares de culto povoam-se de provas que avalizam a existência histórica dessas virtudes (os santos) e as hagiografias encarregam-se de disseminar a sua fama. Os mosteiros e as igrejas são os lugares ideais para esse fim, aos quais a própria aristocracia se associa, por meio das fundações, da participação direta no corpo eclesiástico, e dos enterramentos, que compartilham o mesmo espaço físico dos santos. Ao analisar as famosas hagiografias ibéricas do período, o autor mostra como o discurso que lhes dá sentido assenta-se nas relaçóes de patrocínio, fidelidade e dependência, bem como na afirmação da Igreja como a única ordo capaz de guiar os cristãos à salvação. Da mesma forma, os rituais propiciatórios (oferendas) afirmam e revitalizam a "concepção senhorial das relaçóes sociais fundadas na munificência, na liberalidade característica da aristocracia, mas que atuam em prol do fortalecimento de seu prestígio social, de seu poder e, em última análise, de capacidade de impor-se aos seus dependentes" (p. 229). Oferece-se ao senhor (Deus) náo porque ele precise, mas para que ele restitua os dons, abençoados e multiplicados.

Mas, ficaria ainda uma pergunta: como interpretar a pertinácia daquilo que a autoridade classificava como heresia?

Ora, a contumácia manifesta nessas concepçōes e práticas dissonantes, renitentes e heterodoxas parece-nos revelar um processo muito mais complexo, em seu curso, do que o da suposta unificação religiosa atingida com a "conversão do Ocidente ao cristianismo", complexidade intimamente articulada às contradiçóes sociais intrínsecas à implantação da sociedade senhorial no período, e manifestação vigorosa dos conflitos que matizaram todo seu processo! (p. 233)

Enfim, Mário Jorge Bastos mostrou que assim como as coisas se organizavam na terra, refletiam-se no céu. Para tanto, foi necessário entender que as relações de produção organizavam-se de maneira complexa, sob formas jurídicas, políticas e culturais específicas (tipos de dominação, de coerção, de propriedade e de organização social), presentes desde 
o início do processo como parte constitutiva e primordial. Portanto, não se trata de apresentar essa dimensão como secundária, ou mero reflexo, o que se afasta completamente da ideia de que a base econômica se reflete mecanicamente na superestrutura. Um exercício de história que permite repensar as maneiras como a historiografia tem explicado a "conversão do Ocidente ao cristianismo", bem como acompanhar a renovação da abordagem marxista da História. Mas, diante das dificuldades que a Academia tem para conviver com a pluralidade, talvez o livro seja marxista demais para gregos e marxista de menos para troianos... 